\title{
Environmental Component in Development of Requirements for the Quality of Motor Fuel in Russia
}

\author{
${ }^{1}$ IInar F. Suleimanov, ${ }^{2}$ Gennady V. Mavrin, ${ }^{3}$ IIdar R. Zainutdinov, ${ }^{4}$ Andrey A. Filippov, ${ }^{5}$ Ruslan F. Kalimullin \\ ${ }^{1-3}$ Kazan Federal University \\ 4-5 Orenburg State University \\ Email: ecolog_777@mail.ru
}

Received: 23 ${ }^{\text {rd }}$ July 2019, Accepted: $10^{\text {th }}$ August 2019, Published: 31 $^{\text {st }}$ August 2019

\begin{abstract}
The article is devoted to the analysis and environmental assessment of changes in the regulatory and technical documentation governing the quality of motor fuel in Russia. The quality of motor fuel is understood as a large set of parameters that determine the efficiency and safety of its use for its intended purpose. Ecological safety is revealed as an important component of quality, which is closely connected with other motor characteristics of fuel. The data is analyzed on the influence of additives, supplements and hydrocarbon composition, that is everything that determines the quality of motor fuel and the level of its environmental hazard. The significant role of the environmental component in the development of requirements for the quality of motor fuel has been established and a retrospective has been defined in improving the regulatory and technical control of this issue. A comparison of Russian peculiarities and their connection with global environmental trends in the development of requirements for the quality of motor fuel are provided. The ecological effect of the improvement of the Russian regulatory and technical documentation in terms of the quality of motor fuel has been evaluated.
\end{abstract}

Keywords

EURO Standards, Pollutants, Motor Vehicles, Motor Fuels, Exhaust Gases.

\section{Introduction}

The UNECE Regulations (EURO standards) are constantly being amended to toughen the standards for mass emissions and the amount of controlled pollutants, as well as to complicate test cycles in order to link them to actual operating conditions in a better way. In addition, the amendments take into account the recently widely used hybrid and gas cylinder vehicles.

EURO-5 in comparison with EURO-0 repeatedly reduces emissions of pollutants: CO - $2.72 \ldots 9.3$ times; NOx - 2.4 ... 7.9 times; PM dispersed particles - 20 ... 50 times. A significant variation in numbers is due to the fact that for each category of PBX (taking into account the type of fuel) their its own standards are applied [2, 5].

The theoretical basis. It is important to note that meeting the most stringent environmental requirements for vehicles, nowadays it's EURO-6 in Europe, is impossible without appropriate fuel, the physicochemical and motor properties of which are also strictly regulated by the European Standards EN 228 and 590 [1]. Let us review the process of development of requirements for the quality of motor fuel in Russia (Figure 1) and estimate the impact of its environmental component.

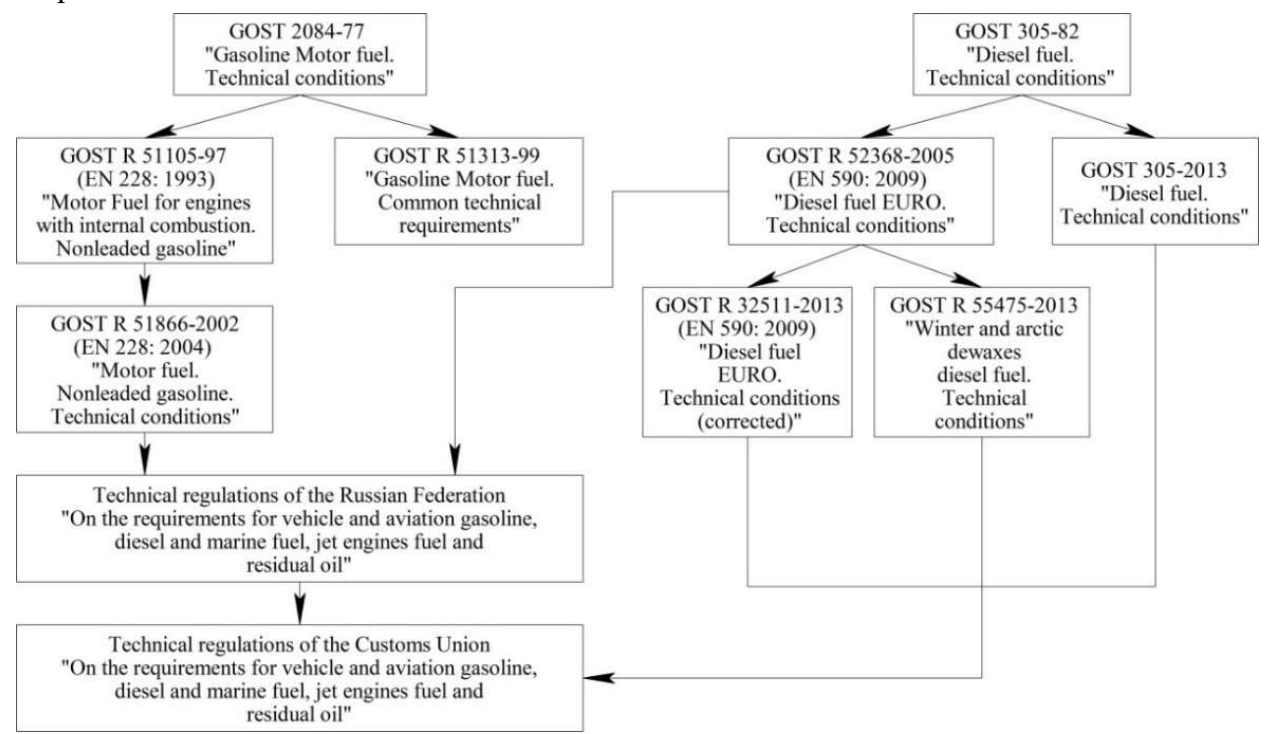

Figure 1: Development of the System of Standards Governing the Quality of Motor Fuel in the Russian Federation 
From Soviet times in Russian Federation, there were two state standards that determined the range, properties and quality of motor fuels produced. These are GOST 2084-77 "Gasoline Motor Fuel. Technical conditions" and GOST 305-82 "Diesel fuel. Technical conditions". The first changes affected gasoline with the introduction of GOST R 51105-97 "Fuels for internal combustion engines. Unleaded gasoline".

The need for such a standard has become apparent with spread of cars in Russian Federation that meet EURO standards and, in this connection, are equipped with exhaust gas neutralization systems. GOST 2084-77 allowed the use of leaded gasoline with a lead content up to $0.17 \mathrm{~g} / \mathrm{dm} 3$, which adversely affected operational efficiency and the resource of neutralization systems.

The introduction of GOST R 51105-97 excluded the use of leaded gasoline, and all metal-containing antiknock additives on the basis of lead, manganese and iron were prohibited. GOST R 51866-2002 "Motor fuels. Unleaded gasoline. Technical conditions " became a logical continuation of GOST R 51105-97 in terms of the distribution of requirements for high-octane grades of unleaded gasoline. If GOST R 51105-97 dealt with only two grades of such gasoline - these are Normal-80 and Regular-92 (the octane number of the research method is at least 80 and 92 , respectively), then GOST R 51866-2002 allowed the existing range to be supplemented - This is Premium EURO 95 and Super EURO 98. It is necessary to add that gasoline Normal-80 and Regular-92, by definition, could not be called EURO, as Premium EURO-95 and Super EURO-98, as in the European regulatory system, according to the European standard EN 228, there is no gasoline with octane rating less than 95 units by research method.

Along with unleaded gasolines that meet the EURO requirements, the use of other gasolines was permitted that satisfy the GOST R 51313-99 "Gasoline Motor fuel. Common technical requirements." which allowed the lead content up to $0.013 \mathrm{~g} / \mathrm{dm} 3$. This regulatory document was a continuation of GOST 2084-77, which has lost its force. The differences were mainly in the values of the octane number for gasoline produced: $72,76,91,93,95$ units by the research method according to GOST 2084-77 and 80, 91, 95, 98 units according to GOST R 51313-99.

The simultaneous existence of GOST R 51105-97, GOST R 51866-2002, GOST R 51313-99 was a compromise between the global environmental trends, technical capabilities and technological equipment of refineries of Russian Federation. The compromise was resolved in favor of global trends, which was manifested by the introduction of Technical Regulations of Russian Federation "On the requirements for vehicle and aviation gasoline, diesel and marine fuel, jet engines fuel and residual oil" in 2008. This technical regulation has become the main mandatory document for manufacturers of automotive motor fuels. According to EURO standards, it defined four ecological classes of unleaded gasoline produced in Russian Federation (GOST R 51313-99 is canceled, which automatically excludes the production of leaded gasoline). Regarding GOST R 51105-97 and GOST R 51866-2002, Russian Federation Technical Regulations were of reference character, that is, they referred to them in terms of the range, requirements for physical, chemical and motor properties of gasoline produced, as well as in terms of methods for testing them [6-9].

At present, the Technical Regulations of the Customs Union "On the requirements for vehicle and aviation gasoline, diesel and marine fuel, jet engines fuel and residual oil" are in force - TP CU 013/2011 (effective in Russian Federation since 2015). In fact, it contains the same requirements as previous Technical Regulations, but is adapted to the conditions of the Customs Union. The TR CU 013/2011 also establishes the ecological classification of gasoline produced in Russian Federation (classes K2, K3, K4, K5) and the validity period (the use of environmental gas not lower than K5 is currently allowed in Russian Federation).

The environmental classification of motor gasoline is based on EURO standards for fuels and, in addition to metalcontaining additives, takes into account other environmental hazards.

Existing technologies for the production of traditional motor fuels may not always provide the required combination of interdependent motor properties. However, the octane number of traditional gasoline can be increased by additives based on lead, iron and manganese, as well as oxygenates - oxygen-containing additives, which are lower alcohols and ethers.

The first method is not acceptable and is prohibited by the current technical regulations of the Customs Union " On the requirements for vehicle and aviation gasoline, diesel and marine fuel, jet engines fuel and residual oil." The ban is primarily related to the high toxicity of metallic additives, especially tetraethyl lead, which, at the exit from the combustion chamber, gives lead oxide ( $\mathrm{Pb} 2 \mathrm{O} 5)$, which has a carcinogenic and mutagenic effect. In addition, they are the cause of carbon formation, reduce the life of spark plugs and catalytic converters.

The second method gives a good result with respect to the octane number, but worsens other motor properties of fuels. In particular, alcohols are toxic (especially methanol), poorly soluble in hydrocarbons, hygroscopic and corrosively active. Petrol-alcohol mixtures damage sealing materials and non-ferrous metals, stratified into separate components at low ambient temperatures. When oxygenates are used, emissions of aldehydes increase 2-4 times and there is a tendency to increase the concentration of nitrogen oxides in exhaust gases. Due to the above reasons, the concentration of oxygenates in motor gasoline is limited, and the methanol content is generally not allowed. For motor gasolines of environmental class K5, the addition of other antiknock agents such as monomethylaniline is also not allowed.

Limiting the use of additives and supplements predetermines the impact on the hydrocarbon composition with an increase in the proportion of aromatic and olefinic hydrocarbons, which contribute to increase in the octane number of gasoline. However, their excessive use leads to carbon formation and emissions of carcinogenic hydrocarbons. Thus, benzene, a typical representative of the aromatic hydrocarbon group, poses a threat both through direct contact with 
gasoline vapors and with the emission of its combustion products with the exhaust gases. Consequently, the change in the hydrocarbon composition of the fuel should also be strictly regulated, which in fact is observed: TR CU $013 / 2011$ limits the content of benzene, other aromatic and olefinic hydrocarbons in gasolines.

The specified prohibitions and restrictions already exist in GOST R 51105-97 and GOST R 51866-2002 (Picture 1). However, they are systematized precisely in the TP CU 013/2011, which reflects the gradual tightening of standards from one ecological class of motor gasoline to another.

The changes also affected diesel fuel (Picture 1). With the introduction of GOST R 52368-2005 (EN 590: 2009) "Diesel fuel EURO. Technical conditions" diesel fuel in Russian Federation was subdivided into regular and EURO. Moreover, GOST 305-82, which regulates the properties of regular diesel fuel, continues to operate in a minor revision in the form of GOST 305-2013. The regulatory document of 2013 is only an adaptation of GOST 305-82 to the conditions of the Customs Union, although it has assumed the character of an interstate standard (within the framework of the Customs Union).

Again, a compromise. On the one hand, EURO diesel fuel with improved properties is produced, designed for vehicles that meet the EURO requirements, which are becoming more and more common in Russian Federation. On the other hand, the production of regular diesel fuel continues, with a high content of sulfur and polycyclic aromatic hydrocarbons, which are the causes of toxic emissions of sulfur oxides, soot and hydrocarbons. Polycyclic aromatic hydrocarbons in diesel fuel are undesirable due to increased soot formation. Together with unburned polycyclic aromatic hydrocarbons carries a carcinogenic hazard.

GOST R 52368-2005 received further development in 2008 in the Technical Regulations of Russian Federation "On the requirements for vehicle and aviation gasoline, diesel and marine fuel, jet engines fuel and residual oil", which refers to it when it comes to assortment, physical - chemical and motor properties of produced diesel fuels. In addition, based on it, GOST 32511-2013 (EN 590: 2009) is formed. "Diesel fuel EURO. Technical conditions (as amended). " The amendment concerned the introduction of an environmental classification of diesel fuels, the terms and conditions for its implementation in the conditions of the Customs Union. GOST 32511-2013 receives the status of interstate in the framework of the Customs Union.

Today, for diesel fuels, as well as for motor gasolines, the main, mandatory regulatory document is TP TC $013 / 2011$. It contains an ecological classification (K2, K3, K4, K5), reflecting the general tendency to toughen environmental standards for diesel fuels in terms of polycyclic aromatic hydrocarbons and sulfur.

In addition, diesel fuel limits the content of fatty acid methyl esters, a component of biodiesel fuel, which is also a sign of the harmonization of Russian and European standards. At the same time, it is allowed to use diesel fuels only of environmental class K5 in Russia.

GOST R 55475-2013 “Winter diesel and arctic dewaxed diesel fuel. Technical conditions" (Picture 1) is valid only in Russian Federation and spreads the requirements of environmental classification in addition to the diesel fuel brands specified in it.

\section{Results}

Thus, the process of changing the requirements for the quality of motor fuel in Russia is largely determined by the environmental component, which is formed on the basis of European standards. Environmental requirements for motor fuels are constantly becoming tougher, which is reflected, above all, in reducing the environmental risk of vehicles operating on it. The authors of this article conducted a study and established a quantitative measure of these changes [10-14]. Below are its results in the form of a comparative assessment of the environmental hazard levels of vehicles operating on AI-93 leaded gasoline according to GOST 2084-77 and AI-92-K5 unleaded gasoline according to TP CU $013 / 2011$, table 1 .

\begin{tabular}{|l|l|l|l|l|l|l|l|l|l|l|l|}
\hline \multirow{2}{*}{ Type of fuel } & \multicolumn{7}{|c|}{ Vehicle Ecological Parameters } \\
\cline { 2 - 14 } & \multicolumn{2}{|l|}{ VHSCO } & \multicolumn{2}{|l|}{ VHSCH } & \multicolumn{2}{l|}{ VHSNOx } & \multicolumn{2}{l|}{ VHSPb } & \multicolumn{2}{l|}{ KOA } \\
\cline { 2 - 13 } & м3/c & $\%$ & м3/c & $\%$ & м3/c & $\%$ & м3/c & $\%$ & м3/c & $\%$ \\
\hline Leaded AI-93 & 5,6 & 0,1 & 4,1 & 0,0 & 332,5 & 3,6 & 9010,1 & 96,3 & 9352,3 & 100 \\
\hline $\begin{array}{l}\text { Unleaded AI-92- } \\
\text { K5 }\end{array}$ & 5,6 & 1,6 & 4,1 & 1,2 & 332,5 & 97,2 & 0,0 & 0,0 & 342,2 & 100 \\
\hline
\end{tabular}

Table 1: Results of a Comprehensive Environmental Assessment of Vehicles Operating on Various Types of Gasoline

The assessment was carried out using a complex environmental parameter - vehicle hazard category (VHC), m3 / s:

$\mathrm{VHC}=\sum_{i=1}^{n} \mathrm{VHS}=\sum_{i=1}^{n}\left(\frac{M_{i}}{\mathrm{MPC}_{i}}\right)^{\alpha_{i}}$,

where VHSi - the hazard category of the i-th exhaust gas pollutant, m3 / s;

$\mathrm{Mi}$ - the amount of emissions of the i-th exhaust pollutant, $\mathrm{g} / \mathrm{s}$;

MPCi - maximum single maximum allowable concentration of the $\mathrm{i}$-th exhaust gas pollutant, $\mathrm{g} / \mathrm{m} 3$;

$\alpha \mathrm{i}-\mathrm{a}$ dimensionless constant that allows to correlate the hazard classes of the $\mathrm{i}$-th pollutant and sulfur dioxide (III hazard class); 
$\mathrm{n}$ - the number of harmful pollutants in the exhaust gases of the car.

KOA shows how much air is needed to dilute the exhaust gases so that the concentration of pollutants does not exceed the maximum permissible concentrations, and is an objective indicator of the environmental hazard of vehicles in terms of composition of the exhaust gases.

\section{Discussion and Interpretation of the Results}

From Table 1 it follows that the main contribution to the formation of the environmental hazard of vehicles is made by nitrogen oxides. Their share for unleaded gasoline AI-92-K5 is over 95.0\%. The remaining pollutants account for less than $5 \%$ of the environmental hazard. However, in the case of running on AI-93 leaded gasoline, the most environmentally hazardous component of exhaust gases is lead. The lead hazard category is $96.3 \%$ of the hazard category of a vehicle operating on this fuel. This means that tightening the requirements only for metal-containing additives with their complete exclusion from gasoline gives a significant environmental effect, expressed in reducing the hazard category of the car by 27 times.

\section{Conclusion}

Thus, the transition from GOST 2084-77 to the TP CU 013/2011 regarding the quality of motor fuel should be considered as a transition to another level - the level of safety for humans and the environment.

\section{Acknowledgements}

The work is performed according to the Russian Government Program of Competitive Growth of Kazan Federal University.

\section{References}

1. Kolodochkin M. Fuel and environmental standards: EURO or GOST // Internet edition "Behind the wheel." URL: https://www.zr.ru/content/articles/904204-evro-v-bake/ (access date: 10.22.2018).

2. Osipyants I. The death of a diesel engine: where else will the introduction of the ecological standard EURO-6 lead to? // Internet edition Za rulyom.rf. URL: https:/www.zr.ru/content/articles/808680-smert-dizelya-k-chemu-eshheprivedet-vevedenie-ekologicheskogo-standarta-evro-6/ (appeal date: 10.22.2018).

3. Suleymanov I.F., Bondarenko E.V., Filippov A.A., Fedotov A.M. Features of the organization of a vehicle in process on environmental criteria // Bulletin of the Irkutsk State Technical University. 2017. V. 21. No. 6. P. $149-158$. 4. Filippov A.A. Improving the efficiency of vehicles operation by selecting alternative types of fuel: Candidate of Engineering Sciences: 05.22.10 / A.A. Filippov. - Orenburg, 2005. - 135 p.

5. Filippov A.A., Dudchenko O.V. The development of the regulatory framework governing the environmental safety of motor vehicles // Bulletin of Orenburg State University. 2015. No. 9 (184). Pp. 200-206.

6. Kulakov A.T. Providing normal conditions of lubricating of diesel engine during its operation / A.T. Kulakov, A.A. Gafiyatullin, E.P. Barylnikova // IOP Conference Series: Materials Science and Engineering. - 2014. - Vol. 69 (1) P.012027.

7. Kulakov A.T. Provision of gas engine bus performance with air-fuel mixture / A.T. Kulakov, I. Gattarov, A.M. Frolov // Journal of Environmental Management and Tourism. - 2015. - Volume 6, Issue 1 (11). - P.91-100.

8. Kulakov A.T. Adaptive system of supplying lubricant to the internal combustion engine / A.T. Kulakov, E.P. Barylnikova, O.A. Kulakov // IOP Conference Series: Materials Science and Engineering. - 2017. - V.240 (1) (International Scientific-Technical Conference on Innovative Engineering Technologies, Equipment and Materials 2016, ISTC-IETEM 2016). - P.012010.

9. Kulakov A.T. Application of electric erosion machining for the restoration of splined surfaces / A.T. Kulakov, E.P. Barylnikova, F.L. Nazarov, Yu. S. Kovalenko, K.V. Gribkov // IOP Conference Series: Materials Science and Engineering. - 2018. - V.412 (International Scientific-technical Conference on Innovative Engineering Technologies, Equipment and Materials 2017 (ISTC-IETEM-2017) 6-8 December 2017, Kazan, Russian Federation). - P.012051.

10. Suleimanov I.F., Mavrin G.V., Kharlyamov D.A., Bondarenko E.V., Kalimullin R.F., Filippov A.A. Assessment of the city air basin pollution using a calculation and instrumental technique. J. Fundam. Appl. Sci., 2017, 9(1S), $1360-1372$.

11. Suleimanov I.F., Mavrin G.V., Kalimulina M.R., Bondarenko E.V., Kalimullin R.F., Filippov A.A. The use of simulation modeling in traffic flow management. J. Fundam. Appl. Sci., 2017, 9(1S), 1840-1848.

12. Suleimanov I.F., Moskova E.V., Sabirov R.G., Kalimullin R.F., Filippov A.A. Organization of vehicle traffic based on environmental monitoring of the air basin. AMAZONIA Investiga, 2018, Vol. 7 Num. 15/Julio-Agosto, 214221.

13. Suleimanov I.F., Moskova E.V., Bondarenko E.V., Shajlin R.T., Filippov A.A. Improvement of system of providing with gas motor fuel .Journal of Advanced Research in Dynamical and Control Systems, 2018, Vol. 10 (13 Special Issue), 564-568.

14. Suleimanov I.F., Sadykova A.R., Sabirov R.G., Filippov A.A. Comprehensive approach to estimation of environmental Hazards of motor transport in industrial city. Journal of Advanced Research in Dynamical and Control Systems, 2018, Vol. 10 (13 Special Issue), 598-605. 